\title{
Socrates in thee Plato's works: uniformity of styles and life in all the works
}

\author{
Azam Etemadifard ${ }^{1, *}$, Malik Hoseyney ${ }^{2}$ \\ ${ }^{1}$ Department of Philosophy, Science and Research branch, Islamic Azad University, Tehran, IRAN \\ ${ }^{2}$ Assistant Professor, Department of Philosophy, Science and Research branch, Islamic Azad \\ University, Tehran, IRAN \\ Email address: etemadifard@ymail.com
}

Keywords: Socrates, Plato, Socratic style, Socratic life.

\begin{abstract}
Despite the fact, only one of the Plato's treatises among his coaction of works is titled "Defending Socrates"; however, one can say that all the Plato's works are based on defense of Socrates. Meanwhile, they are founded on defending Socratic thoughts, manners and finally his life. Some scholars have considered historic Socrates as being distinct from the Platonic Socrates with regards to the Plato's thoughts. The author intends, contrary to that which is famous regarding Socrates inthe Plato's works, to see the Socratic life and manner as being uniform in all the works; Hence based on this uniformity, the principles governing on his original philosophical life have been inferred from the content of his thoughts.
\end{abstract}

\section{INTRODUCTION}

If we accept the words of Whitehead that "Philosophy is either an explanation or interpretation of Plato or criticism of him" (Burn, 2005), one can state that the decent father of philosophy has stood on the zenith of philosophy. A philosopher who along with his works, placed Socrates, his own master on the outset of philosophy and through this left behind a model of philosophizing and an example of life as being dedicated to seek truth and good. The Plato's Socrates is an intellectual who teaches us his thoughts that that which we think we know about privileges is not correct; hence we cannot show them in a practical life and as a result we shall not have a good life and thus, we cannot have a feeling of happiness and fortune. The significance of the Socratic life is as much significant as that of every human being who seeks happiness and good fortune. The Plato's treatises, except for one of them are all in form of conversations between two or several people and in all of which, one of the parties to the talks is Socrates who is mainly the most important person; although he is sometimes insignificant and is finally removed in the Laws Treatise (Plato, 1997). Some of the scholars do not see a uniform thought or personality for Socrates in all the works; hence the historic Socrates in the works ofthe first era is seen as being separable from the Platonic Socrates in later eras. In a coherent plan, we seek an interpretation of the Plato's works with whichone can delineate some coherent Socrates life and styles despite the fact he has been assigned different roles in the works. This will help us to have a Platonic Socrates being uniform throughput the works.

\section{Socrates style}

To explain a Socratic style, the terms used by Socratesfor describing his own style need to be applied in brief so that one can infer a methodological principle with respect to him. These terms are:

\section{Dialogue (discourse)}

In his discussions with pupils and the laymen, Socrates started a question and made them to answer; hence he elaborated on the answer provided by the audience and yet made himanswer another question and hence this chain would continue so that the latter party would recognize the 
fact the he needed to answer the questions with care and exactness. In all the stages, Socrates mentioned the definitionsthrough patience and leniency and gentleness so that the latter party would not fall into sense of humiliation and credulity and hence can understand the facts through thoughts and proper recognition. Interchange with others regarding truths was a fundamental methodological approach which led him to be a prominent figure in the history of mankind despite the fact he did not have a written work.

The selection of this paradigm for philosophy cannot assume its own position disregard of attention to the nature of the Plato's Socrates and relations of words with the truth. There are toomany truths that cannot be explained through speech and in form of words. Language can describe facts inthe world in which we live, but the nature of the Socrates'thoughts wants to unveil the most original belonging of thinking which is the foundation of the tangible world existence where it calls for our own; with others being unable to express it in form of words and should one attempt to explain it through determinism as it is, it will be null and void and hence you will be called a madman. In this case, is the paradigm of dialogue in form of question and answer without attempting to give an absolute answer and issue a dogmatic judgment not better and do "the Socrates' I don't know" and "I cannot express my own ideas" lead others towards truths whose characteristic is being inexpressible? Philosophy aims towards the truth of being and seeking of it. Thus, if it is not placed in form of an open form, it will be captured by the words and closed thoughts. Though despite the fact dialogue is open, words by themselves are still poor against such that it bows down to the unconditional order of transcendence(sublime orders) and seeks for assistance was for seeking truth. The Plato's Socrates' philosophy is the same seeking and search and the words and awakening of others as much and for this awakening speech is not the touchstone for truth rather it represents it in the person, however in companionship with an association where there is a consensus about it. Even Socrates is not rightful regarding that which is said in such a way in many of the dialogues the discussion end up in deadlock and the speech by the two sides will end in futile.

Examples of this futility could be witnessed in the treatise by Esoferon regarding religiosity, in treatise by Karmidous in discussion of reservation and in Losis. The thinking between these questions and answers will reveal in speech conflicts and contradictions and this continuous move will make you aware of ignorance. Until you do not step in this field, you suspect you know it in as much as you are not ready to learn and if you ever intend to learn, there shall be no content in a closed and definite end. It is for this reason that dialogue is the way for representation of truth provided that it is honestly and intimately accompanied internal and spiritual cooperation of the two sides. The way for truth for people seeking it stands against them in a live manner and writing if replace dialogue, this will in accordance with Socrates make people distance from each other and it is not deemed a decent intermediate between people. The Platonic Socrates' dialogues are accompanied by intimacy, optimism and mutual respect and do differ with those of street people and hence cannot tolerate the sophists' sermons intended with dominating the rival and success in any way.

\section{The Socratic irony of I don't know}

In his life, Socrates never claimed to know. This was the best privilege he had compared to others who knew that he did not know while others did not know that they did not know. Under such conditions Socrates used the instrument of irony so to inculcate others in their own and hence later this program of his was made famous as the Socratic irony. The goal of the Socrates' irony was not to make the rival come clean and to destroy him; rather it was toassist him to de-chain him and make his inward ready for accepting the truths (Guardini, 1996). He was not satisfied with his own moral and spiritual state against the rival and comprehended the difficulty of this state and used to communicate to the rival he was not better than him and this way would help both of whom to continue with the cooperation; the inward of humans could witness some sort of tumult and thus their souls became conscious' Being conscious of the fact he is on the way seeking truth and the 
way is so long that he cannot understand and hence one cannot deceive himself and allow for rage to over dominate him rather he needs to know that our lives has the irony of Socrates inside itself, whether we accept this reality or not; whether wanting to know but not to say it tha5t we know and not trusting the same we suspect to know. However, this is Plato who highlighted the Socratic irony and one can search for the same irony in himself. Romano Guardini considered the Plato's irony as another kind which is neither rooted in the contradiction of his character nor in refraining from a direct philosophical expression. Rather it is founded on the feature of his artistic talent and his philosophical universality. This universal philosophy has revealed to him that how in the essence of man, transcendental perfection has intermingled with the earthly drawbacks and where absolute has joined relative and in light of it, the artistic talent has managed to find out what facilities the Socrates' personality has brought about for depicting all these forces (Guardini, 1996).

\section{DIALECTICS}

Dialectics, for Plato's Socrates is a royal art that rules overall bodies of knowledge (Esomodoud, 291 C). It is like a crown over the head of all bodies of knowledge and wise people where no body of knowledge is thought of being better and superior to it. Because it is the ultimate level of knowledge (Republic, $534 \mathrm{C}$ ). Through all these phrases and an overlook to the Plato's Socrates conversations, dialectics will be the same philosophy and based o its methodology, in the first stage, it is a direction internally and spiritually so that man reaches a position where he turns back on all the representations and turn to a world of reality and eternal existence beingunchangeable. In the second stage, it is a special way in discussion and discourse meaning someone who has by himself gone through that internal direction, via the dialectical methodology, he will get the rival reach the point where he will once find out he has already been entangled with the riches a $\mathrm{d}$ his thoughts had been founded on deceptions; thus he needs to rise from the representations and riches and seek truth somewhere else (Plato, 2000). In this discussion and reasoning which is brought in form of question and answer, the intention is to get the interlocutors understand their own ignorance regarding truth and fundamental issues of the human life which is basis for knowledge.

The Plato's Socrates has expressed dialectics in all his works in different grounds. In Mannon(75 C), it is a method against the proponents of sophistry; in Esermodous (290C), the discovery of astrologists and geometry scientists need to be provided to the proponents of dialectics; in Keratolous (390C), it is higher than the mathematics bodies; it is going through love stages and intuition of the beauty itself where in the Republic it is stipulated that such things are specific to the proponents of the dialectics. According to the Books 6 and 7 of Republic, it is the most supreme research and deals with the highest subject matter, i.e.example of good which is expressed in form of three allegories of Sun, Line and Cave while its trend ranges from tangible to reasonable top absolute good. All these statements communicate to us the fact that in the end, philosophy for the Plato's Socrates is the same Dialectics and the essence of dialectics is movement so that it breaks up any systems of closed intellect. If at first, discourse is aimed at stimulating thoughts, it thus becomes thinking itself such thinking via which the unseen, partial, transient realms turn into a uniform meaning.Dialectics is the movement of thinking from the surface, from symbols to the essence and it is briefly a short movement of humans from a seen world towards the world of meaning (Naghibzade, 2009).

This movement is a transcending move whose dimension is descending trend and return from a unified ides towards plurality. Here, we speak of trends and direction and seeing and finding out which differ with science accomplishments a d logic which are learnable; because thought is not pure rather it is a symbol of spiritual life. This will make man move between darkness and lighting and philosophy is the way towards seeking being along with awareness and that's why through Plato's' Socrates we quote dialectics as the crown and royal art over the top of all bodies of knowledge through which we can coordinate our life as we demand (Gadmer, 1989). 


\section{MIDWIFERY}

Socrates tells Theatetous: " Have you ever not heard that I'm a son of a midwife and my mother Finarter has been a respectable midwife?... .Have you ever heard that I'm a well-known midwife? So, know I am a midwife but do not tell this secret to others, because no one knows that I have such a profession and they are not aware of my profession... It is claimed I am an astonishing man that makes everyone feel doubtful (Theatetous,149a). In interpreting the midwifery of Socrates we read in Plato that:

The art of midwifery holds true for my profession too with the difference being that I help men rather women to bear easily and hence I make the souls of men bear not their bodies and the biggest privilege of my art is that when a man is on the verge of delivering, I know whether he will deliver an incomplete baby or a genuine baby. I am also similar to a midwife in another direction and that I will never produce a body of knowledge and those who reproach me that I always ask others and I do not provide the answers myself because I do not know a persuading answer. They are right and now listen to my reasons. God has assigned me help others bear while he has not given me the talent of making people pregnant nor the ability to bear. Hence, neither do I have knowledge nor has ever my soul managed to produce knowledge. Those who initiate a talk with me areat first thought dumb butt since they accompany me, should God help them with His mercy, their states will be better and thus I will help them to bear that which is spiritual and fruitful for them (Theatetous, 150-151- c). Socrates has inherited this technique of midwifery from mother, the differencebeing that he uses this technique regarding women (Plato,2009). This technique is established in form of question and answer without the answer have ever been clarified so that discussions are not get oriented and hence two or several people reach an Irony of I don't know and at last a mysterious secret of truth. Now, we can express the truth behind the Socratic style. He looks at his relation with himself through an ascending direction in form of absolute good and approaches a transcendental intuition step by step.

\section{SOCRATIC LIFE}

\section{Socrates' death}

At the Greek courthouse, the most wise and intellectual man of his own time was sentenced to death and this event was made known as the "death of Socrates". The latent message with the Socrates' death cannot be apprehended except for the type of look at his life. Comprehension of the life truth from the perspective of Socrates hinges upon comprehension of the truth appertaining to the Socrates' thinking. Via his death, he made clear life as being centered over seeking for truth and true existence that would call us towards it. If Socrates did not create any distinction between life and death over ideas he had found to have been correct and considered the value of living as beyond as mere being or not being, we need to consider the Socrates' life as the same Socratic thinking and his thinking as his life. His life in relation with others, God and others and taken its meaning from some sort of philosophical and practical thinking; hence the meaning and content of his thinking must be explored.

\section{Themes of the Platonic Socrates' thinking}

\section{Foundation and basics of everything}

That which pertains to the Platonic Socratic thinking is a transcendental affair upon which everything hinges and everything owes its own lighting on it.An affair to which any knowing and anting and ability owe their content and most sophists are ignorant of which and the same ignorance has changes and transformed the life of laymen such that its depth has declined. In opposition to the thinking movement of the sophists who and founded the basis of everything as hovering around doubts and suspensions, the Platonic Socrates, via criticism and tests had showed that lies a fixed 
and unconditional affair behind all this instability governing over thinking and behaviors of the latter that could be called truth. He considered this truth as single, decent idea, decent itself, and beauty itself and to the author "God himself" which navigates our lives and hence our existence is once signified where our thinking and life are directed at that true unity.

This foundation and basic is not of the concepts; hence its placement in form of speech aimed at its explanation hits the wall while concepts and ideas are signs for finding a way towards it. There is a way towards it but there is no reaching. One should not deny it or feel he is in vacuum; if one does so, he only reproaches himself; because this shows a slip in the kind of one's life which is only relied on feeling and shadow, turning to shadow affairs being mortal. The latter can remind one towards it and awaken him,however it cannot teach him in form of words and speech. One has to be taught step by step so that decent idea stands against him and through this state, his life will be teemed with enthusiasm and eagerness.

\section{Human truth}

The Platonic Socrates considers the human existential truth as soul where this truth needs to turn to myth and allegory and he himself has done so; however, this is a figurative sense and is aimed for approaching to our mindset. He says: "To describe the idea of soul, there is a need for a detailed divine expression while we can produce allegories through a short and human expression" (Fiderosus, 246 a). The reason for this gets back to the fact that we are in relation with some transcendental affair and there is a close relationship between us an heavenly existence... because we are not earthly creatures rather our essence is heavenly and by the time we are created, our soul has come down from there and joined us (Themauss, 90b) and also the divine truth is immortal and able to think... while the body is immortal and temporary being unable to think, transforming into states each day. It is also sentenced to be in service of God while the soul rules (Fidon, 80b). Hence, its existence is truth and the very human being.

Sophists were not denying the existence of soul but they were not in a position to completely understand the depth and expansiveness of soul and accept that all of our life truths were related with it in all personal, life and cultural and politicalarenas. Meanwhile, the truth of man's existence is the soul. For Socrates of Plato, one can only reach the understanding of truth through divine aspects of that which is the Wisdom and hence it is related with truth and the wisdom is the same soul with a life force. Therefore, identification is that state should takes when it pays attention to that which is living. (Theatous, $187 \mathrm{a}$ ). This message is the sameSocratic message which became the foundation and basic of his thinking in his life; something that had been craved over the eve of the Delphi temple: "Know yourself". This message, for Socrates communicates that idea that wisdom is the same as self-recognition and a life without wisdom is meaningless; either he realizes it has become meaningless and states that while he does not understand fails to state. This selfrecognition is deep and is somethingbeyond the attention of the sophists at humans who did not consider a strong basis for man. The Socrates' call for Self and human's truth is the call for opening a way inside us towards basics of the existence of everything.

\section{Idea or truth of everything in the world of ideas}

Our thinking goes towards everything that exists so that we find understanding and knowledge about it (Republic, 477 a). If our thinking was aimed at mortal and transformable existences such that it was achieved by a sense of knowledge, it could not be a true knowledge. However, if our thinking goes towards fixed and changeableaffairs that could truly be called they exist, true knowledge will be achieved. For Platonic Socrates, these affaors are general and do not lack an objective reference and hence are called ideas (Kaplstone, 1995). Idea for the Platonic Socrates involves various concepts such as an overall concept, meaning, truth, essence, forms, essence of example and being of everything (Naghibzade, 2009). He has variously thought of ideas and these thinking are in such a way that through which one cannot obtain a coordinated and orderly 
comprehension of ideas. Attention to the idea of beauty and moral ideas like good and evil and courage and reservation and even religiosity are among the Socrates' interests; however, he actually address mathematical concepts like shapes and numbers and the like and then to general concepts of natural shapes, specificallyconcepts like humans and horses and the like (Kaplstone, 1995). For the Platonic Socrates, understanding ideas can be made possible by traversing into that world so to go beyond the concrete so that we can be successful to encounter everything through which that exists. This is the same philosophy or dialectics of the Plato's Socrates.

\section{Virtue}

Most translators of Platonic Socrates, in German, English, Persian and French as quoted by Lotfi, use the word virtue as equivalence for arête. The reason why is because of the meaning load of the word for Greek people where no equivalencecould be found for that inother neither languages norvirtue can be an equivalence for it. Therefore, the word arête has found different meanings throughout the Greek dictionary; however for the Platonic Socrates, arête is everything that is the transcendental level and the perfection level of the main feature of that thing; feature that we expect of everything; feature to which the value and nobility of something does depend; feature, in case of its absence, that thing cannot be made available as its true meaning. For example, the arête of a knife is sharpness and tat of hose is speed while that of a dog is watching and guarding and even one can speak of the arête of eyes and ears.

Arête is not human specific; however arête of humans is the most complete and transcendental actualization of special capabilities and competencies as a living creature. In other words, after we realize that what duties man does possess based ion his nature which is found to be his distinction between himself and other living creatures; we can say that the arête of humans is completion of these duties in the noblest form. Socrates was not the only one to have paid attention to arête; because humans have virtues and it is always expected for them; however at that time possessing virtue as based on habits and customs. He called upon the people of his time to converse about virtues which they thought they were in possession of it so that they would find out what the true virtue is and what effects it has in the human soul not to rely on superficial concepts and meanings and act to do so as Socrates wanted. The very virtue itself requires that knowledge based on which in all stats a d situations man can act usefully on virtue. Humans, while being united with the very virtue will be a man teemed with truths of virtues; he is a philosopher that has the wisdom and can rule (Republic $473 \mathrm{~d}$ ) provide that sophists, claiming teaching of any sort of virtue tolerate that the genuine knowledge is not limited to that which is common to anytime. However, the Socrates of all Plato's works had a coordinated life style which is called honesty (Aristotle, 2010). He lost his life in the way for this honesty and this direction is taken from some principles which are as follow:

1. Through truth, seek truth

2. Find your originality through wisdom

3. Wisdom, religiosity, justice, courage and reservation are genuine virtues of man

4. Honesty is the coordination of thoughts and practice in your direction

5. Happiness is the governance of these principles over your life

\section{CONCLUSION}

Socrates thinks in an ascending way and via his thinking style, he obtained principleshe had found himself and it is true that he was living so coordinately with these principles that even sentence to death did not prohibit him from that and since then his historic life began. The Socrates ' thinking was the philosophy itself; his style was the crown of knowledge and an original philosophical life; hence he is himself a philosopher and this himself is the truth of everything. 


\section{References}

[1] Aristotle. (2010). Machos decent idea, Translated by Lotfi, Mohamd Hasan. Tehran: Tarhe Now publication.

[2] Plato (2000). Era of Platonic works, Translated by Lotfi, Mohamd Hasan, , Kaviani , Mohamad Reza. Tehran: Kharazmi publication.

[3] Plato (2009). Six treatises (Socrates and Plato's wisdom), Translated BY Foroughi, Mohamad Ali. Tehran: Hermess publication.

[4] Burn, Jean. (2005). Socrates, Translated by Pour Husseini, Abolghasem. Tehran: Soroush cultural and scientific institute.

[5] Kaplstone, Fredrick. (1995). History of philosophy in Greece and Rome. Tehran: Soroush cultural and scientific institute.

[6] Guardini, Romano. (1994). Death of Socrates, Translated byLotfi, Mohamd Hasan. Tehran: Ghiam publication.

[7] Naghibzade, Mir Abdul Hussein. (2009). an introduction to Philosophy. Tehran: Tahoori publication.

[8] Gadamer, Hanse-George. (1998). The idea of the good in Platonic-Aristotelian philosophy, Tr. To En. By Christopher Smith, Yale University, Chps III.IV.

[9] Plato, (1997). Plato complete, Ed By Johan Cooper, Indian Polis and Cambridge. 